\title{
Production, chemical composition, and quality of Arabic coffee subjected to copper doses
}

\author{
Herminia Emilia Prieto Martinez ${ }^{(1)}$, José Soares de Lacerda(1), Junia Maria Clemente(1), Jaime Barros da \\ Silva Filho ${ }^{(1)}$, Adriene Woods Pedrosa( ${ }^{(2)}$, Ricardo Henrique Silva Santos ${ }^{(1)}$ and Paulo Roberto Cecon ${ }^{(3)}$
}

\begin{abstract}
(1)Universidade Federal de Viçosa (UFV), Departamento de Fitotecnia, Avenida P.H. Rolfs, s/no, Campus Universitário, CEP 36570-000 Viçosa,MG,Brazil.E-mail:herminia@ufv.br,j_s_lacerda@hotmail.com,junia.clemente@gmail.com,jaimeufv@yahoo.com.br,rsantos@ufv.br (2)Empresa de Pesquisa Agropecuária de Minas Gerais, Campus UFV, Caixa Postal 216, CEP 36571-000 Viçosa, MG, Brazil. E-mail: awoodsp74@gmail.com (3)Universidade Federal de Viçosa (UFV), Departamento de Estatística, Avenida P.H. Rolfs, s/noo, Campus Universitário, CEP 36570-000 Viçosa, MG, Brazil. E-mail: cecon@ufv.br
\end{abstract}

Abstract - The objective of this work was to evaluate the effect of copper on the chemical composition of coffee beans and on the quality of the beverage, relating both of them to the $\mathrm{Cu}$ leaf contents in coffee (Coffea arabica) plants. Coffee plants were grown in a hydroponic system containing 0.2, 0.4, 0.8, 1.6, and $3.2 \mu \mathrm{mol} \mathrm{L}-1 \mathrm{Cu}$ until fruit setting. Coffee bean production was evaluated, and, after the cherries were dried, the following characteristics were determined: leaf $\mathrm{Cu}$ content; total titratable acidity; color index; electrical conductivity; leached K; polyphenol oxidase (PPO) activity; concentrations of caffeine, trigonelline, organic acids, total phenols, chlorogenic acids (3-CQA, 4-CQA, and 5-CQA), sucrose, glucose, arabinose, mannose, and galactose; and sensory quality of roasted beans. $\mathrm{Cu}$ increased bean yield, PPO activity, and the concentrations of organic acids, 3-CQA, sucrose, and arabinose. Total titratable acidity, total phenols, 4-CQA, and 5-CQA were reduced with increasing $\mathrm{Cu}$ doses. Leaf contents related to the maximum and minimum values of desirable and undesirable quality attributes ranged from 5.6 to $11.4 \mathrm{mg} \mathrm{kg}^{-1} \mathrm{Cu}$, respectively. Copper affects the production and chemical composition of coffee beans, and the attributes related to quality are maximized in plants with low leaf contents of the nutrient.

Index terms: Coffea arabica, nutrition, sensory analysis.

\section{Produção, composição química e qualidade de café arábica submetido a doses de cobre}

Resumo - O objetivo deste trabalho foi avaliar o efeito do cobre na composição química dos grãos de café e na qualidade da bebida, bem como relacionar ambas aos teores foliares de $\mathrm{Cu}$ do cafeeiro (Coffea arabica). Cultivaram-se cafeeiros em sistema hidropônico com 0,2, 0,4, 0,8, 1,6 e $3,2 \mu \mathrm{mol} \mathrm{L}^{-1} \mathrm{de} \mathrm{Cu}$ até a produção de frutos. Avaliou-se a produção do café, e, após secagem dos grãos maduros, determinaram-se: a concentração foliar de cobre; a acidez total titulável; o índice de coloração; a condutividade elétrica; o K lixiviado; a atividade da polifenoloxidase (PPO); as concentrações de cafeína, trigonelina, ácidos orgânicos, fenóis totais, ácidos clorogênicos (3-CQA, 4-CQA e 5CQA), sacarose, glicose, arabinose, manose e galactose; e a qualidade sensorial dos grãos torrados. $\mathrm{O} \mathrm{Cu}$ aumentou a produção de grãos, a atividade de $\mathrm{PPO}$ e as concentrações de ácidos orgânicos, 3-CQA, sacarose e arabinose. A acidez total titulável, os fenóis totais e o 4-CQA e o 5-CQA foram reduzidos com o incremento das doses de $\mathrm{Cu}$. Os teores foliares relacionados aos valores máximos e mínimos dos atributos de qualidade desejáveis e indesejáveis variaram de 5,6 a $11,4 \mathrm{mg} \mathrm{kg}{ }^{-1}$ de $\mathrm{Cu}$, respectivamente. $\mathrm{O}$ cobre afeta a produção e a composição química dos grãos de café, e os atributos relacionados à qualidade são maximizados com baixas concentrações foliares do nutriente.

Termos para indexação: Coffea arabica, nutrição, análise sensorial.

\section{Introduction}

The characteristic coffee flavor derived from the bean is directly related to edaphoclimatic conditions, cultivars, soil or leaf fertilization, and post-harvest processing, which includes drying, storage, roasting, grinding, and packaging. Several chemical constituents of the bean, such as aroma, flavor, acidity, body, astringency, and residual taste, among others, are responsible for the characteristics of the beverage, and their proportion or combinations will define its quality (Buffo \& Reineccius, 2008). 
The chemical composition, and qualitative and quantitative variations of coffee beans were investigated according to species (Monteiro \& Farah, 2012), cultivar (Kitzberger et al., 2013), and also to processing, growing environment, and management (Ribeiro et al., 2016). Among the chemical components of the raw coffee beans, chlorogenic acids, caffeine, trigonelline, phenols, and sucrose are closely related to the sensory quality of the beverage and are used in its classification (Farah et al., 2006).

Copper constitutes and activates several enzymes such as polyphenol oxidase and diamine oxidase, which catalyze the oxidation of phenolic compounds to ketones, considered precursors of lignin (Hänsch $\&$ Mendel, 2009; Pilon et al., 2006). The activity of the polyphenol oxidase enzyme in raw beans has been used as a biochemical indicator of beverage quality, since the best quality coffees show a greater activity of this enzyme and have a higher color index (Carvalho et al., 1994; Mazzafera et al., 2002; Silva et al., 2009).

Although minerals act in many of the metabolic pathways that form the compounds that give coffee its quality, there are few studies relating the nutritional status of coffee plants to the quality of the beverage. Nitrogen and potassium nutrition affects the chemical composition of the raw bean, which, after toasted, produces compounds that give aroma and flavor to the coffee (Clemente et al., 2015). However, studies on the micronutrients and the formation of compounds desirable for the quality of the beverage are restricted to the effect of zinc (Martinez et al., 2013); there are no known reports on the relationship between $\mathrm{Cu}$ and the quality of coffee beans.

The objective of this work was to evaluate the effect of $\mathrm{Cu}$ on the chemical composition of coffee beans and on the quality of the beverage, relating both of them to the $\mathrm{Cu}$ leaf contents in coffee plants.

\section{Materials and Methods}

The experiment was conducted in a greenhouse at the Department of Plant Science of Universidade Federal de Viçosa (UFV), located in the municipality of Viçosa, in the state of Minas Gerais, Brazil, between August 2010 and August 2013. Plants of the Catuaí Vermelho IAC 99 coffee (Coffea arabica L.) cultivar were grown in nutrient solution under increasing $\mathrm{Cu}$ doses.
Before the beginning of the experiment, plagiotropic branches of 'Catuaí Vermelho IAC 99' were grafted on rootstocks of the same cultivar to reduce the size of the plants. After wound healing, the plants were maintained in containers with aerated nutrient solution containing $6.0 \mathrm{mmol} \mathrm{L}^{-1} \mathrm{~N}, 0.5 \mathrm{mmol} \mathrm{L}^{-1} \mathrm{P}, 3.23$ mmol L-1 K, $2.25 \mathrm{mmol} \mathrm{L}^{-1} \mathrm{Ca}, 1.0 \mathrm{mmol} \mathrm{L}^{-1} \mathrm{Mg}, 1.75$ $\mathrm{mmol} \mathrm{L}-1 \mathrm{~S}, 23 \mu \mathrm{mol} \mathrm{L}-1 \mathrm{~B}, 2.0 \mu \mathrm{mol} \mathrm{L}^{-1} \mathrm{Zn}, 12 \mu \mathrm{mol} \mathrm{L}^{-1}$ $\mathrm{Mn}, 0.3 \mu \mathrm{mol} \mathrm{L}{ }^{-1} \mathrm{Mo}$, and $40 \mu \mathrm{mol} \mathrm{L}{ }^{-1} \mathrm{Fe}$, according to Clemente et al. (2015). The plants were kept in halfstrength nutrient solution until two leaf pairs were reached. At this stage, plants were transplanted into 11-L containers filled with acid-washed river sand over a 2-cm layer of expanded clay on the bottom, to which was added a full-strength solution. After one year, the plants were transferred to 20-L containers in the same conditions as previously described.

Data were collected in the second production cycle, because bean production in the first one was insufficient for all evaluations. The experiment was arranged in a completely randomized design, consisting of the following $\mathrm{Cu}$ doses: $0.2,0.4,0.8,1.6$, and $3.2 \mu \mathrm{mol} \mathrm{L}^{-1}$ supplied via nutrient solution, with three replicates per treatment. The experimental plot consisted of two containers, each with one plant.

Replicates of the same treatment were connected to a reservoir with $50-\mathrm{L}$ capacity containing the corresponding nutrient solution. Every 3 hours, the plants were irrigated with the respective solutions. The nutrient solutions percolated the sand bed and returned to the same reservoir, where they remained until the next irrigation shift. At night, the system was kept turned off.

The volume of solution evapotranspirated per treatment was refilled daily with deionized water until the initial volume of $50 \mathrm{~L}$ was reached. The solution $\mathrm{pH}$ of each reservoir was adjusted daily to $5.5 \pm 0.5$ with $\mathrm{HCl}$ or $\mathrm{NaOH}$, and the solutions were replaced whenever the electrical conductivities reached $70 \%$ of the values measured in the fresh solutions. The sand and expanded clay of the substrate were washed and disinfected, and the stock solutions of macronutrients and chelated iron used in the preparation of the nutrient solution were purified as described by Martinez \& Clemente (2011).

The plants were kept under a shading screen blocking $50 \%$ of the incident radiation. During the experiment, the temperature inside the greenhouse was between the maximum of $45^{\circ} \mathrm{C}$ and the minimum of $12^{\circ} \mathrm{C}$. 
At the beginning of flowering, leaves of the third or fourth node of the flowering plagiotropic branches were collected to evaluate the nutritional status of the plants. The samples were washed in deionized water, oven dried at $70^{\circ} \mathrm{C}$ for 72 hours, and ground in a Wiley mill.

Coffee beans were picked individually at the cherry stage, and production per plant (gram per plant) was recorded in each plot. Beans were dried on a paper towel until 11 to $12 \%$ moisture, hulled, and subjected to the chemical analysis.

$\mathrm{Cu}$ leaf contents were determined by atomic absorption spectrophotometry according to the method of Silva (2009) with modifications.

The relationship between the $\mathrm{Cu}$ dose of the solution and the $\mathrm{Cu}$ content of the diagnostic leaves was obtained by $\hat{\mathrm{Y}}=3.1025+3.1907 \mathrm{Cu} ; \mathrm{r}^{2}=0.98$. This equation was also used to estimate the following leaf contents related to the bean chemical characteristics that maximize quality: total titratable acidity (TA); color index; electrical conductivity (EC); leached $\mathrm{K}$ (LK); polyphenol oxidase (PPO) activity; and concentrations of caffeine, trigonelline, organic acids, total phenols, chlorogenic acids (3-CQA, 4-CQA, and 5-CQA), sucrose, glucose, arabinose, mannose, and galactose.

TA (mL of $0.1 \mathrm{~N}^{\mathrm{mol} \mathrm{L}} \mathrm{L}^{-1} \mathrm{NaOH}$ per $100 \mathrm{~g}$ sample) and total phenolic compounds (gallic acid equivalents) were determined by the method of Helrich (1990). The organic acids (malic, tartaric, and citric) were obtained by high-performance liquid chromatography with the C18 reversed-phase column, according to Scherer et al. (2012). PPO activity was determined with DOPA (3,4-dihydroxyphenylalanine) substrate as recommended by Carvalho et al. (1994).

The 3-CQA, 4-CQA, and 5-CQA chlorogenic acids were extracted and clarified as described by Farah et al. (2005). Caffeine and trigonelline were determined as in Mazzafera et al. (2002), and proanthocyanidins as in Hagerman (2002).

Sucrose and reducing sugars (glucose, mannose, arabinose, and galactose) were quantified following Sluiter et al. (2008).

The color index was obtained by the method modified for coffee described by Singleton (1966), and LK and EC were determined according to Loeffler et al. (1988).

Professional testers of the company Três Irmãos Corretora de Café (Viçosa, MG, Brazil) performed the sensory evaluation (cup testing) of the samples, and the results were converted into the following numerical values for the statistical analysis: 88 , strictly soft; 80 , soft; 70, softish; 60, hard; 59, hard/riado; 58, fermented hard; 57, hard/riado/rio; 55, riado; 53, riado rio; 50, rio; and 45 , rio zona.

Data were examined by the analysis of variance and regression analysis, using the SAEG software, version 9.0 (Universidade Federal de Viçosa, Viçosa, MG, Brazil). The regression analysis was used to evaluate the effects of $\mathrm{Cu}$ doses. The models were selected based on the significance of the regression coefficients by the t-test, at $5 \%$ probability; on the biological phenomenon; and on the coefficient of determination.

\section{Results and Discussion}

Coffee bean yield showed a significant quadratic response to $\mathrm{Cu}$ doses. Its peak was of $38.6 \mathrm{~g}$ per plant at the estimated dose of $1.45 \mu \mathrm{mol} \mathrm{L^{-1 }} \mathrm{Cu}$ and $\mathrm{Cu}$ leaf content of $7.20 \mathrm{mg} \mathrm{kg}^{-1}$ (Figure 1).

It should be noted that doses higher than 1.45 $\mu \mathrm{mol} \mathrm{L}{ }^{-1} \mathrm{Cu}$ reduced bean production. This response to the increase in $\mathrm{Cu}$ supply is related to the role of this micronutrient in the plant's photosynthesis, respiration, carbohydrate metabolism, nitrogen metabolism, antioxidant activity, lignification process (Pilon et al., 2006; Hänsch \& Mendel, 2009), and pollen grain formation (Dell, 1981). Gontijo et al. (2008) found a strong reduction in growth, plagiotropic branches, leaf area, and dry matter accumulation in 'Topázio MG 1190' coffee plants cultivated for 250 days in $\mathrm{Cu}$-deficient nutrient solution. However, in the present study, the reduction at $\mathrm{Cu}$ doses higher than $1.45 \mu \mathrm{mol} \mathrm{L} \mathrm{L}^{-1}$ (Figure 1) may be related to the negative interactions between $\mathrm{Cu}$ and other cations, since excess $\mathrm{Cu}$ induces the deficiency of $\mathrm{Fe}, \mathrm{Zn}$, and $\mathrm{Mn}$ due to their similar ionic radii (Sagardoy et al., 2009).

The leaf content associated with maximum yield was below the range of $13-29 \mathrm{mg} \mathrm{kg}^{-1}$ considered adequate for field conditions by Martinez et al. (2003), but very close to the range of $8-16 \mathrm{mg} \mathrm{kg}^{-1}$ considered adequate by Malavolta (1993). The low leaf contents obtained in this study are probably due to the lack of leaf contamination in the greenhouse environment.

The maximum production per plant was also low because the plants were conducted with only one primary plagiotropic branch, which was grafted onto 
the main orthotropic branch, whose apical bud was removed. This procedure was done to provide early fruiting in smaller plants, which are suitable for cultivation in nutrient solution with strict control of $\mathrm{Cu}$ supply, but would not be obtained under usual growing conditions.

TA was significantly affected by $\mathrm{Cu}$ doses and was fitted to the quadratic root model; the lowest value of $115.57 \mathrm{~mL} 0.1 \mathrm{~N} \mathrm{NaOH} 100 \mathrm{~g}^{-1}$ was obtained at the estimated dose of $1.75 \mu \mathrm{mol} \mathrm{L}-1 \mathrm{Cu}$ (Figure 1). At the point of minimum acidity, the $\mathrm{Cu}$ leaf content was 9.75 $\mathrm{mg} \mathrm{kg}^{-1}$ and the estimated bean yield decreased slightly to $37.95 \mathrm{~g}$ per plant. According to Carvalho et al. (1994), TA has an inverse relationship with the quality of the coffee beverage; however, in the present study, although there was a significant effect of the $\mathrm{Cu}$ doses on this characteristic, the lowest and the highest TA of 115.57 and $138.450 .1 \mathrm{~N} \mathrm{NaOH} 100 \mathrm{~g}^{-1}$, respectively, were below the values of $250.4,272.2$, and $284.5 \mathrm{~mL}$ $0.1 \mathrm{~N} \mathrm{NaOH} 100 \mathrm{~g}^{-1}$ reported by these authors for hard, riado, and rio coffees, that is, $\mathrm{Cu}$ had no marked effect on the TA of the coffee beans produced. It should be highlighted that low acidity values are characteristic of specialty coffees.

The concentrations of organic acids in the coffee beans increased with increasing $\mathrm{Cu}$ to a threshold from which $\mathrm{Cu}$ excess had an adverse effect on that characteristic (Figure 2). The variation in the concentration of tartaric acid with $\mathrm{Cu}$ doses fitted to the quadratic root model; the highest concentration of $2.72 \%$ was obtained at the estimated dose of 1.0 $\mu \mathrm{mol} \mathrm{L} \mathrm{L}^{-1} \mathrm{Cu}$, decreasing to $2.04 \%$ at the highest $\mathrm{Cu}$ dose of $3.2 \mu \mathrm{mol} \mathrm{L}{ }^{-1}$, which represents a reduction of $25 \%$. The concentration of citric acid also fitted to the quadratic model, with the highest content of $1.16 \%$ at the estimated dose of $0.63 \mu \mathrm{mol} \mathrm{L}{ }^{-1} \mathrm{Cu}$. The lowest content of citric acid was $1.05 \%$ at the highest $\mathrm{Cu}$ dose of $3.2 \mu \mathrm{mol} \mathrm{L} \mathrm{L}^{-1}$, a $10 \%$ reduction in relation to the content estimated at the maximum point of $1.16 \%$. Malic acid responded similarly to the other acids, with the highest content of $0.30 \%$ at the estimated dose of $1.97 \mu \mathrm{mol} \mathrm{L}^{-1} \mathrm{Cu}$. The leaf contents corresponding to the points of maximum concentration of the tartaric, citric, and malic acids were $6.29,5.11$, and $9.39 \mathrm{mg} \mathrm{kg}^{-1}$, respectively.

The maximum concentrations of citric and malic acids found in the present study are close to those of 1.12 and $0.33 \%$, respectively, reported by Kitzberger et al. (2013) for cherry beans of 'Catuaí Vermelho IAC 81'. It should be noted that organic acids are non-volatile components of coffee acidity and that malic and citric acids have been associated with a good quality beverage (Carvalho et al., 1997).

$\mathrm{Cu}$ doses also significantly affected the phenolic content of coffee beans. The increase in $\mathrm{Cu}$ doses promoted a decline, followed by a subsequent increase in phenolic contents, which fitted to the quadratic model, with the lowest content of $6.10 \%$ at the estimated dose of $1.55 \mu \mathrm{mol} \mathrm{L}^{-1}$ and $8.05 \mathrm{mg} \mathrm{kg}^{-1} \mathrm{Cu}$ leaf content (Figure 3). The lowest phenolic content found by Kitzberger et al. (2013) was 4.55\% in cherries of 'Catuaí Vermelho IAC 86' cultivated in the field.
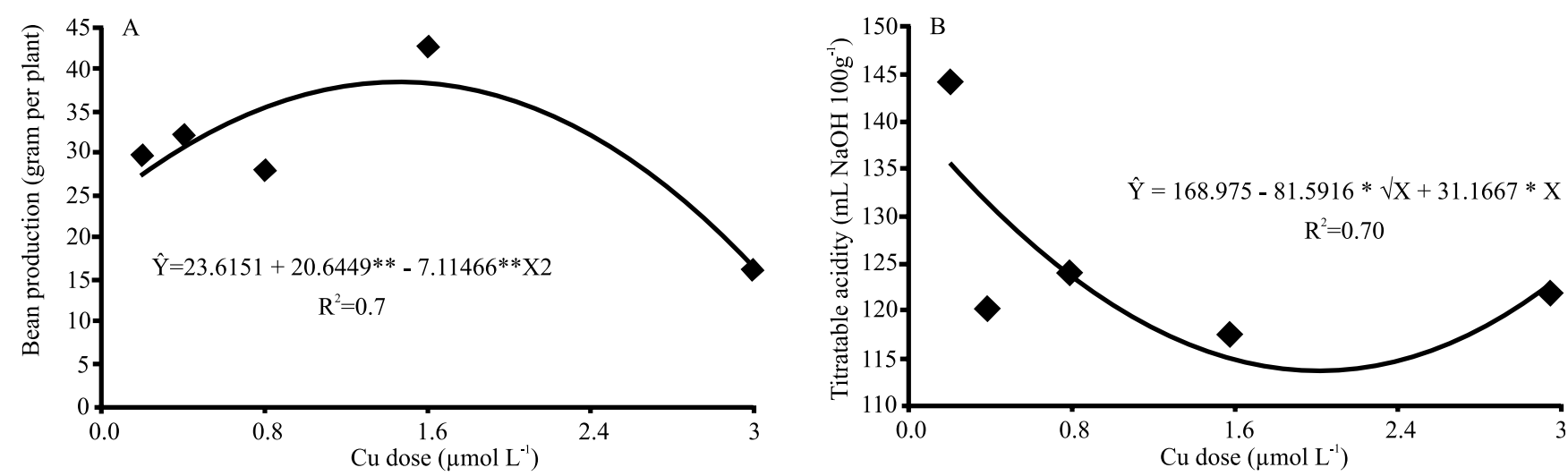

Figure 1. Bean production and total titratable acidity of raw 'Catuaí Vermelho IAC 99' coffee (Coffea arabica) beans as a function of the copper doses in the nutrient solution used for growing the plants. * and **Significant by the t-test, at 5 and $1 \%$ probability, respectively. 
The reduction in phenolic content with higher $\mathrm{Cu}$ doses is directly related to the role of $\mathrm{Cu}$ in the secondary plant metabolism, i.e., in the lignification and formation of melanocytic substances, since the enzymes that oxidize phenols into lignin and other compounds are activated by $\mathrm{Cu}$. Consequently, the
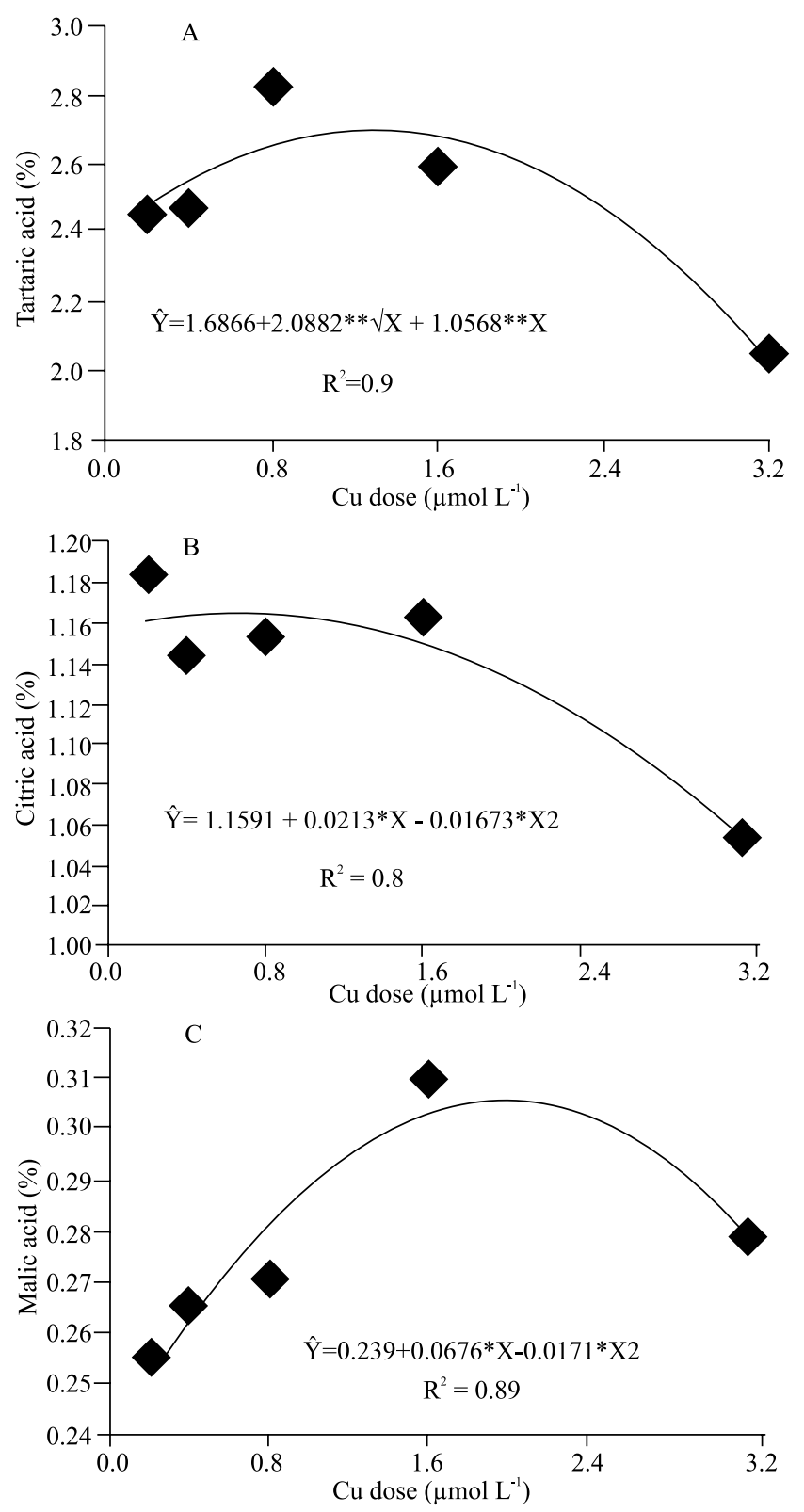

Figure 2. Content of tartaric (A), citric (B), and malic (C) acids in raw 'Catuaí Vermelho IAC 99' coffee (Coffea arabica) beans as a function of copper doses in the nutrient solution used for growing the plants. * and **Significant by the t-test, at 5 and $1 \%$ probability, respectively. higher the $\mathrm{Cu}$ content in the plant, the higher the activity of these enzymes and the lower the phenolic content. $\mathrm{Cu}$ deficiency reduces the activity of the enzymes that oxidize phenols into lignin, resulting in an accumulation of phenols and in a decrease in lignification (Pilon et al., 2006; Hänsch \& Mendel, 2009).

The PPO activity responded to $\mathrm{Cu}$ doses in a quadratic trend, with the highest enzyme activity of $81.35 \mathrm{Ug}^{-1}$ of sample at the estimated dose of 0.78 $\mu \mathrm{mol} \mathrm{L}{ }^{-1} \mathrm{Cu}$ (Figure 3) and $5.6 \mathrm{mg} \mathrm{kg}^{-1} \mathrm{Cu}$ leaf content. The lowest PPO activities (77.85 and $65.23 \mathrm{U} \mathrm{g} \mathrm{g}^{-1}$ ) were found at the lowest and highest $\mathrm{Cu}$ doses, respectively. $\mathrm{Cu}$ is essential for PPO activity, as it participates in its structure as a prosthetic group; therefore, its effect on the activity of this enzyme was expected.

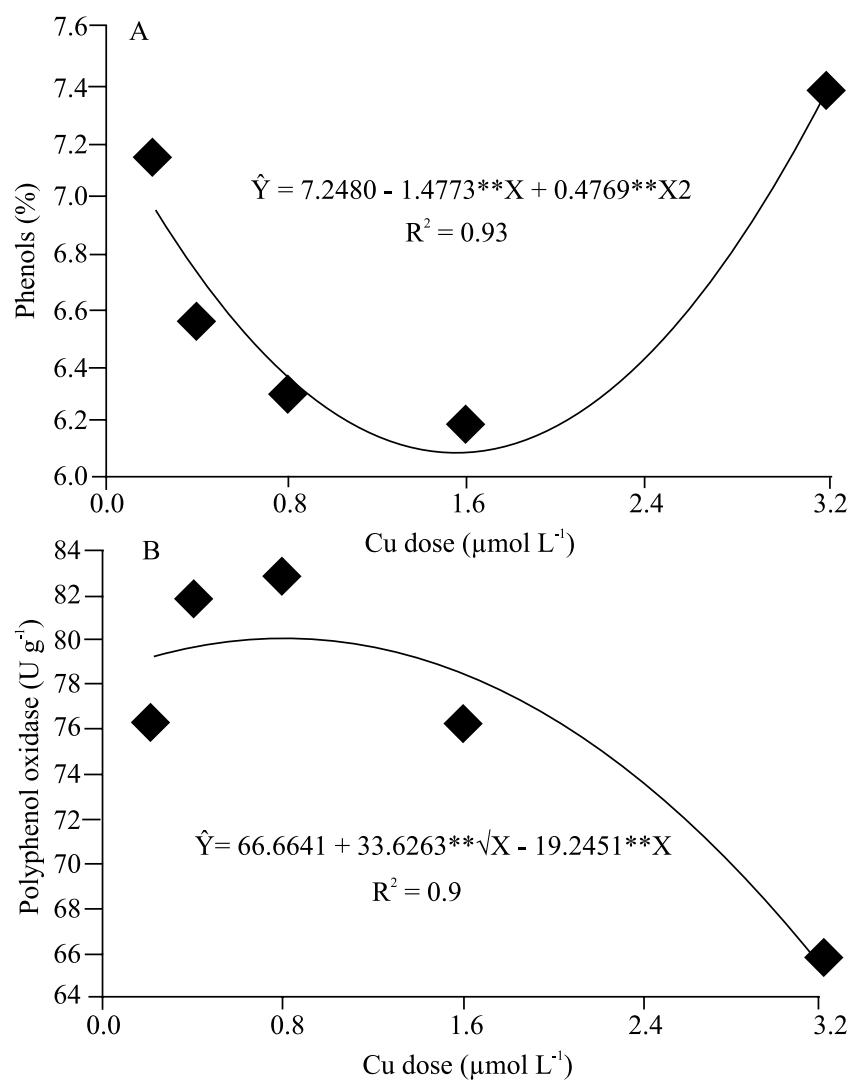

Figure 3. Content of phenols (A) and polyphenol oxidase activity (B) in raw 'Catuaí Vermelho IAC 99' coffee (Coffea arabica) beans as a function of copper doses in the nutrient solution used for growing the plants. * and **Significant by the t-test, at 5 and $1 \%$ probability, respectively. 
The association between PPO activity and beverage quality has been reported by several authors (Amorim \& Silva, 1968; Carvalho et al., 1994; Mazzafera et al., 2002) and used as a biochemical indicator of coffee quality (Carvalho et al., 1994). However, there is a certain discrepancy between the $\mathrm{Cu}$ doses that provided the highest bean yield (1.45 $\mu \mathrm{mol} \mathrm{L}^{-1}$; Figure 1$)$ and the

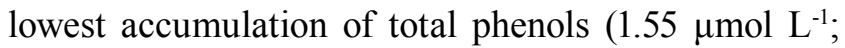
Figure 3$)$, and the $\mathrm{Cu}$ dose $\left(0.78 \mu \mathrm{mol} \mathrm{L}^{-1}\right)$ that provided the highest PPO activity (Figure 3). Therefore, it is possible to infer that the $\mathrm{Cu}$ doses that maximize bean production may not be the same ones that provide better sensory quality. Nevertheless the reduction in production at the $\mathrm{Cu}$ dose that provided the highest PPO activity was $7 \%$, which is a very small percentage.

Carvalho et al. (1994) proposed that PPO activities below $55.99 \mathrm{U} \mathrm{g} \mathrm{g}^{-1}$ of sample indicate riado and rio coffees; between 55.99 and $62.99 \mathrm{U} \mathrm{g}^{-1}$, hard coffees; between 62.99 and $67.66 \mathrm{U} \mathrm{g}^{-1}$, soft coffees; and above $67.66 \mathrm{U} \mathrm{g} \mathrm{g}^{-1}$, strictly soft coffees. According to this classification, the beverage in the present study would be considered strictly soft at $\mathrm{Cu}$ doses lower than $3.05 \mu \mathrm{mol} \mathrm{L}^{-1}$ and as soft at higher doses (Figure 3), which has a good correspondence with the sensory analysis (cup testing) (Table 1) and confirms the strong association between PPO activity and the sensory classification of the beverage.

The contents of 5-CQA produced a quadratic response to $\mathrm{Cu}$ doses. There was a decrease and subsequent increase with increasing $\mathrm{Cu}$ doses, with the lowest content of $0.97 \%$ at the estimated dose of 1.62 $\mu \mathrm{mol} \mathrm{L}{ }^{-1} \mathrm{Cu}$ (Figure 4). Interestingly, the reduction in 5-CQA with increasing $\mathrm{Cu}$ doses was inversely proportional to PPO activity, which is considered as

Table 1. Sensory analysis (cup testing) of processed 'Catuaí Vermelho IAC 99' coffee (Coffea arabica) beans subjected to copper doses in the nutrient solution of the plants.

\begin{tabular}{lccc}
\hline $\begin{array}{l}\text { Cu doses } \\
\left.(\mu \mathrm{mol} \mathrm{L})^{-1}\right)\end{array}$ & Classification & Scores & Attribute \\
\hline 0.2 & Soft beverage & 82 & Good body (GB) and balanced \\
0.4 & Soft beverage & 82 & Good body \\
0.8 & Soft beverage & 82 & Good body, sweet, and balanced \\
1.6 & Soft beverage & 82 & Balanced and velvety body \\
3.2 & Soft beverage & 84 & Sweet, GB, fruity, and winey \\
\hline Mean & & $\hat{\mathrm{Y}}=82.4$ & \\
$\mathrm{CV}(\%)$ & & 2.72 & \\
\hline
\end{tabular}

a biochemical indicator of coffee quality (Figure 3). There are studies reporting that lower-quality coffees have higher concentrations of polyphenols, such as chlorogenic acids (Carvalho et al., 1994), and higher levels of 5-CQA (Farah et al., 2006).
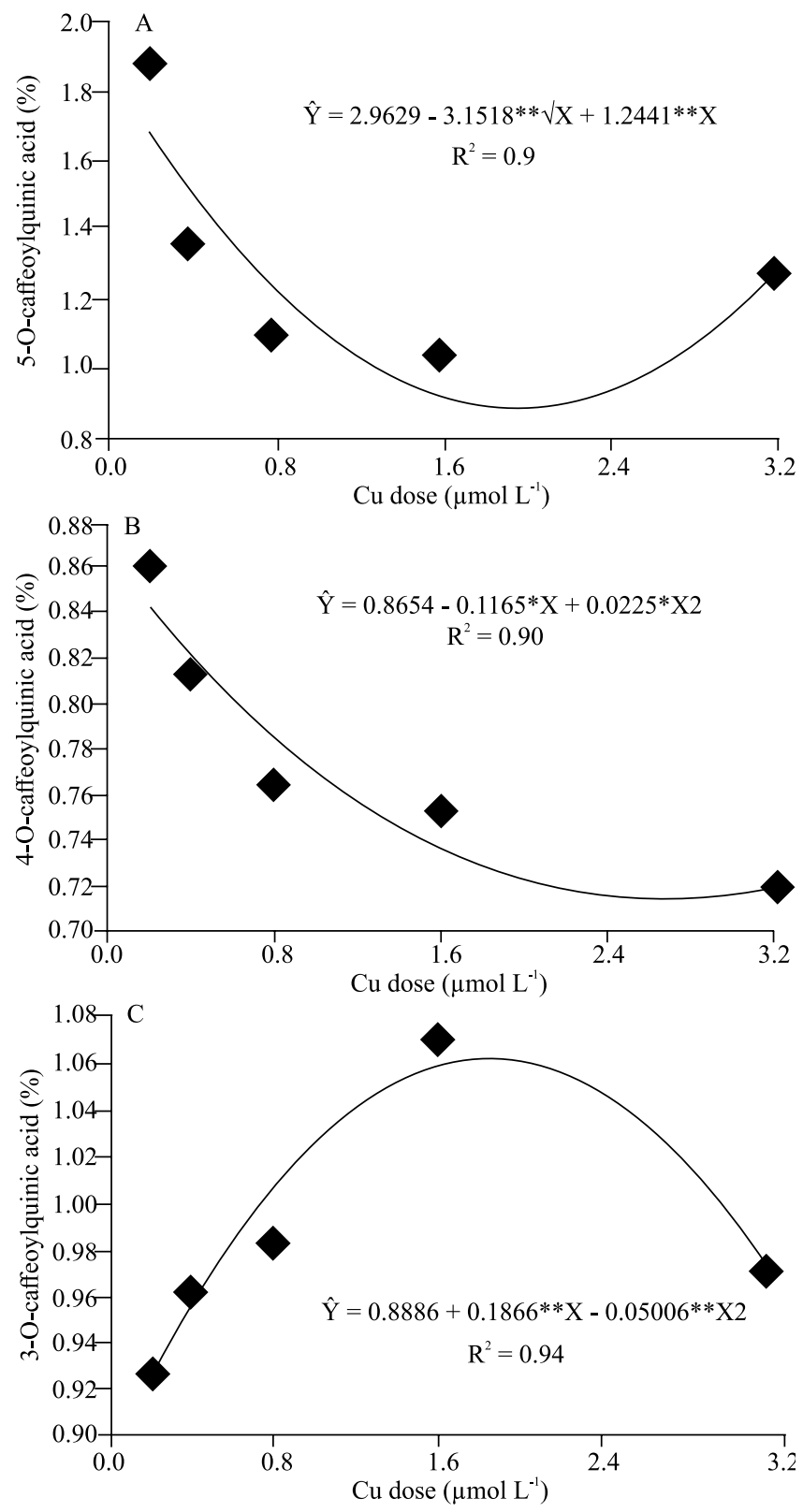

Figure 4. Content of 5-O-caffeoylquinic acid (A), 4-O-caffeoylquinic acid (B), and 3-O-caffeoylquinic acid (C) in raw 'Catuaí Vermelho IAC 99' coffee (Coffea arabica) beans as a function of copper doses in the nutrient solution used for growing the plants. * and **Significant by the t-test, at 5 and $1 \%$ probability, respectively. 
Similar to 5-CQA, the contents of 4-CQA decreased with increasing $\mathrm{Cu}$ doses and increased again after a minimum point, producing a quadratic response, with the lowest content of $0.71 \%$ at the estimated dose of $2.59 \mu \mathrm{mol} \mathrm{L}^{-1} \mathrm{Cu}$ (Figure 4). Conversely, the levels of 3-CQA increased with increasing $\mathrm{Cu}$ doses, fitting a quadratic model, with the highest content of $1.06 \%$ at the estimated dose of $1.86 \mu \mathrm{mol} \mathrm{L}^{-1} \mathrm{Cu}$, corresponding to a $15 \%$ increase in the 3 -CQA content in relation to the lowest $\mathrm{Cu}$ dose, followed by a reduction of $9 \%$ at the maximum $\mathrm{Cu}$ dose. Based on the behavior of 3-CQA, which was opposite to that of 5-CQA and 4CQA, but directly proportional to that of PPO activity (Figure 3), the 3-CQA content can be associated with good coffee quality. It is possible that the accumulation of 3-CQA shows a positive effect by limiting the concentrations of 4-CQA and mostly 5-CQA, which is the main substrate of PPO. According to Salva \& Lima (2007), coffee with lower levels of chlorogenic acids provide less astringent and more characteristic beverages. The authors pointed out that bitterness, astringency, and mold taste in the beverage are due not only to the contents of these acids, but also to the proportions in which they are found in raw coffee. The leaf concentrations of $\mathrm{Cu}$ associated with the maximum or minimum concentration of 5-CQA, 4-CQA, and 3-CQA were at the lowest limit of the range considered adequate for coffee, i.e., 8.27, 11.37, and $9.03 \mathrm{mg} \mathrm{kg}^{-1}$, respectively.

The contents of caffeine, trigonelline, and proanthocyanidins were not affected by $\mathrm{Cu}$ doses, and

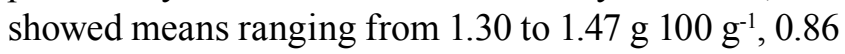
to $1.10 \mathrm{~g} 100 \mathrm{~g} \mathrm{~g}^{-1}$, and 6.17 to $6.26 \mathrm{mg} \mathrm{g}^{-1}$, respectively (Table 2). While evaluating 'Catuaí Vermelho IAC 86', Kitzberger et al. (2013) found similar contents for caffeine, the main bitter compound in coffee, and for trigonelline, which degrades into volatile compounds responsible for the aroma during roasting (Farah et al., 2006). In the present study, the accumulation of proanthocyanidins, which are compounds partially responsible for the astringency in coffee, was higher than the concentrations between 3.47 and $5.48{\mathrm{~g} 100 \mathrm{~g}^{-1}}^{-1}$ reported by Morais et al. (2009) for 'Conilon' Coffea canephora Pierre ex A.Froehner.

The sucrose content in beans varied according to a quadratic function with the increasing $\mathrm{Cu}$ doses in the nutrient solution. The highest sucrose content of $8.88 \%$ was recorded at the estimated dose of $1.80 \mu \mathrm{mol} \mathrm{L}-1$ (Figure 5), corresponding to a $21 \%$ increase in the sucrose content of $7.33 \%$ at the lowest $\mathrm{Cu}$ dose.

At the maximum $\mathrm{Cu}$ dose, the sucrose content was reduced by $15 \%$ compared with the estimated dose at the maximum point. However, the $\mathrm{Cu}$ dose of $1.80 \mu \mathrm{mol} \mathrm{L}^{-1}$ that promoted the highest production of sucrose was slightly higher than the one of 1.45 $\mu \mathrm{mol} \mathrm{L}{ }^{-1}$ that resulted in maximum bean yield, i.e., the $\mathrm{Cu}$ dose that optimized the concentration of the main sugar present in the coffee beans reduced production by $2.3 \%$. The $\mathrm{Cu}$ leaf content at the point of maximum sucrose production was $8.85 \mathrm{mg} \mathrm{kg}^{-1}$.

Sucrose represents almost all free sugar in cherry beans and affects the quality of the beverage as an important precursor of flavor and aroma (Farah et al., 2006). The sucrose contents found in the present study are in the range of 5.1 and $9.4 \%$, considered adequate by Campa et al. (2004) for cherries of C. arabica, and the maximum content of $8.8 \%$ was higher than that of $7.9 \%$ reported by Kitzberger et al. (2013) for 'Catuaí Vermelho IAC 86'. These results are explained by the fact that approximately $50 \%$ of the $\mathrm{Cu}$ in plants is located in the chloroplasts, in the plastocyanin, where the nutrient participates in the transfer of electrons in

Table 2. Mean concentrations of caffeine (CAF), proanthocyanidins (PRO), trigonelline (TRIG), mannose (MAN), galactose (GAL), and leached potassium (LK), as well as color index (CI) and electrical conductivity (EC) of raw 'Catuaí Vermelho IAC 99' coffee (Coffea arabica) beans subjected to copper doses in the nutrient solution of the plants.

\begin{tabular}{|c|c|c|c|c|c|c|c|c|}
\hline $\begin{array}{l}\mathrm{Cu} \\
\left.(\mu \mathrm{mol} \mathrm{L})^{-1}\right)\end{array}$ & 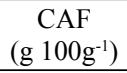 & $\begin{array}{c}\text { PRO } \\
\left(\mathrm{mg} \mathrm{g}^{-1}\right)\end{array}$ & 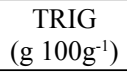 & $\begin{array}{c}\text { MAN } \\
(\%)\end{array}$ & $\begin{array}{l}\text { GAL } \\
(\%)\end{array}$ & $\begin{array}{c}\mathrm{LK} \\
\left(\mathrm{g} \mathrm{kg}^{-1}\right)\end{array}$ & $\begin{array}{c}\text { CI } \\
(\mathrm{OD} 435 \mathrm{~nm})\end{array}$ & 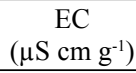 \\
\hline 0.2 & 1.30 & 6.26 & 0.861 & 0.27 & 0.12 & 0.943 & 0.85 & 244.3 \\
\hline 0.4 & 1.46 & 6.25 & 0.862 & 0.22 & 0.10 & 0.692 & 0.77 & 218.0 \\
\hline 0.8 & 1.46 & 6.17 & 1.103 & 0.23 & 0.11 & 0.836 & 0.74 & 221.6 \\
\hline 1.6 & 1.47 & 6.21 & 0.948 & 0.25 & 0.10 & 0.952 & 0.80 & 224.0 \\
\hline 3.2 & 1.39 & 6.18 & 0.891 & 0.26 & 0.11 & 1.000 & 0.85 & 268.0 \\
\hline CV (\%) & 12.97 & 0.88 & 8.92 & 6.53 & 1.92 & 15.04 & 18.44 & 11.99 \\
\hline
\end{tabular}


the photochemical phase of photosynthesis (Hänsch \& Mendel, 2009), which affects the production of sucrose and other sugars. Brown \& Clark (1977) observed a severe reduction in the concentration of reducing sugars in branches of $\mathrm{Cu}$-deficient wheat (Triticum aestivum L.) plants in the reproductive phase.
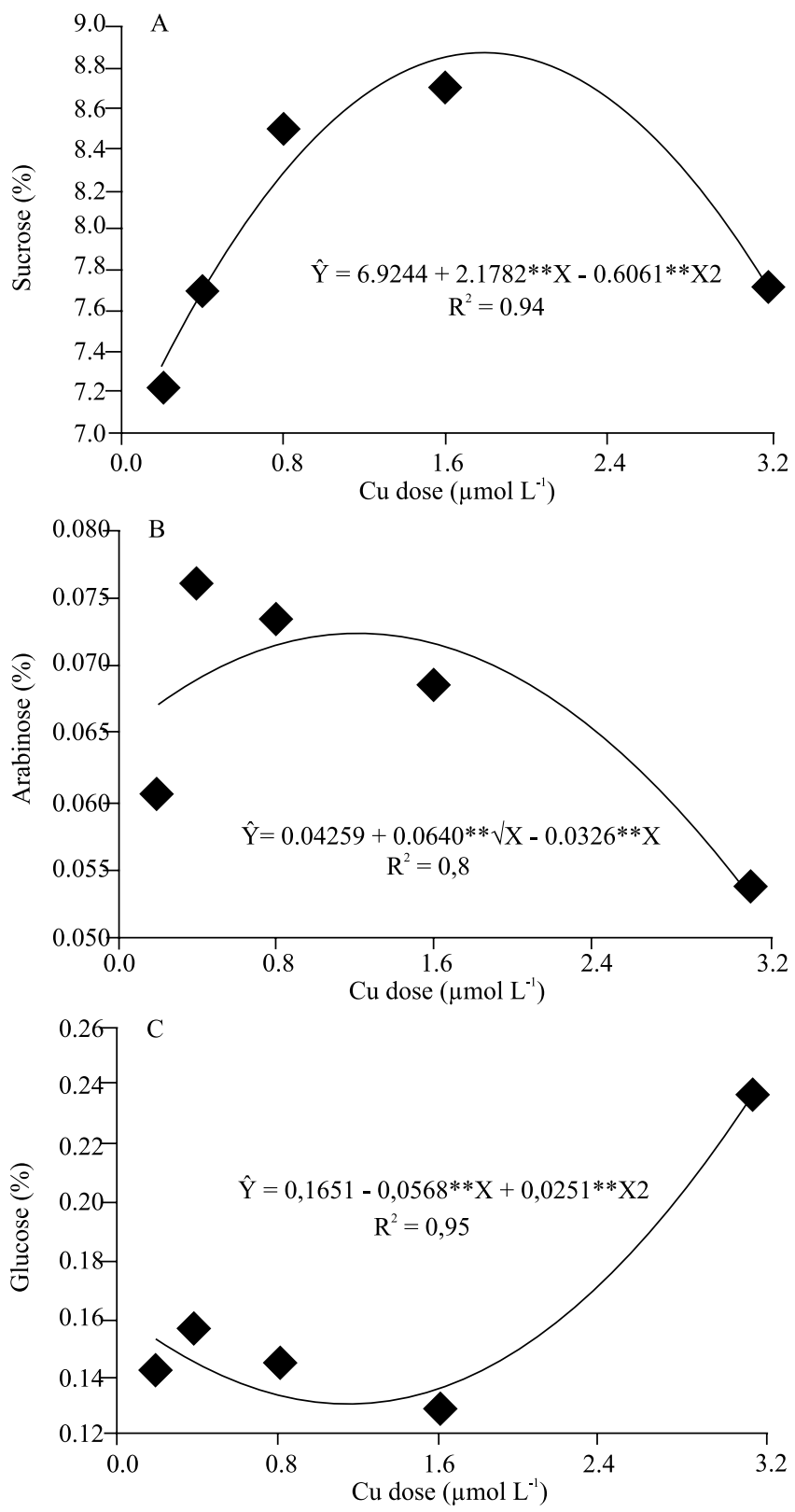

Figure 5. Content of sucrose (A), arabinose (B), and glucose (C) in raw 'Catuaí Vermelho IAC 99' coffee (Coffea arabica) beans as a function of copper doses in the nutrient solution used for growing the plants. * and **Significant by the t-test, at 5 and $1 \%$ probability, respectively.
The contents of arabinose and glucose were also affected by $\mathrm{Cu}$ doses (Figure 5). The arabinose content increased in a quadratic trend with increasing $\mathrm{Cu}$ doses, and the highest content of $0.074 \%$ was recorded at the estimated dose of $1.0 \mu \mathrm{mol} \mathrm{L}^{-1} \mathrm{Cu}$. This result corresponded to a $14 \%$ increase in arabinose content, which was $0.065 \%$ at the $0.2 \mu \mathrm{mol} \mathrm{L}^{-1} \mathrm{Cu}$ dose. At the maximum $\mathrm{Cu}$ dose of $3.2 \mu \mathrm{mol} \mathrm{L}{ }^{-1}$, arabinose content was $0.053 \%$, indicating a $40 \%$ reduction compared with the dose at which the maximum content was obtained. The increase in $\mathrm{Cu}$ doses reduced the glucose content, whose lowest content was $0.13 \%$ at the estimated dose of $1.13 \mu \mathrm{mol} \mathrm{L}{ }^{-1} \mathrm{Cu}$. However, at the maximum $\mathrm{Cu}$ dose of $3.2 \mu \mathrm{mol} \mathrm{L}^{-1}$, the glucose content increased by $85 \%$, reaching $0.24 \%$. $\mathrm{Cu}$ doses caused no changes in mannose and galactose contents, which were on average 0.24 and $0.11 \%$, respectively (Table 2). The leaf contents associated with maximum and minimum concentrations of arabinose and glucose were 6.29 and $6.70 \mathrm{mg} \mathrm{kg}^{-1}$, respectively.

The soluble sugars in coffee beans include glucose, fructose, mannose, galactose, and sucrose. They are responsible for the sweetness in the beverage, one of the most desirable flavor attributes in specialty coffees (Marques et al., 2008). High concentrations of sugars in raw coffee beans significantly affected the Maillard reactions during roasting (Mendonça et al., 2007) and, consequently, the quality of the beverage.

$\mathrm{Cu}$ doses had no significant effect on the color index (Table 1), which was on average 0.80 OD $435 \mathrm{~nm}$. According to several authors, higher quality coffees have higher PPO activity and color index (Carvalho et al., 1994; Silva et al., 2009). They pointed out that coffees with color indexes equal to or greater than 0.65 were classified as hard, softish, soft, and strictly soft; while coffees with color indexes lower than 0.65 (OD $435 \mathrm{~nm}$ ) were classified as rio and riado, that is, were non-exportable coffees (Carvalho et al., 1994).

LK and EC showed no response to $\mathrm{Cu}$ doses (Table 2), with means of $0.88 \mathrm{~g} \mathrm{~kg}^{-1}$ and $235.18 \mu \mathrm{S} \mathrm{cm} \mathrm{g} \mathrm{g}^{-1}$, respectively. Higher potassium leaching and a consequent increase in EC indicate membrane and cell wall damage (Goulart et al., 2007). As expected, $\mathrm{Cu}$ did not play a prominent role in these characteristics, which is in alignment with its functions in the plant's metabolism.

The sensory analysis showed no significant difference among $\mathrm{Cu}$ doses in the nutrient solution. The 
coffee attributes varied according to the highest and lowest $\mathrm{Cu}$ doses; however, in general, the beverages were classified as soft (Table 1). This indicates that a balanced $\mathrm{Cu}$ nutrition, although fundamental in the production of quality-related compounds, plays a secondary role in the quality of the beverage, compared with maturation degree and post-harvest processing of the cherry beans, which were carefully dried in the present study.

\section{Conclusions}

1. Copper affects coffee (Coffea arabica) bean production and changes chemical characteristics of raw beans.

2. $\mathrm{Cu}$ has a positive effect on the concentrations of sucrose, arabinose, and of the tartaric, citric, malic, and 3-CQA acids, as well as on the polyphenol oxidase (PPO) activity of coffee beans; and the maximum concentrations of these compunds are found in plants with leaf contents at or below the lower limit of the sufficiency range of the nutrient.

3. $\mathrm{Cu}$ has a negative effect on the concentrations of total phenols, 5-CQA, 4CQA, glucose, and total titratable acidity of coffee beans; and the minimum concentrations of these compounds are obtained in plants with leaf contents at or below the lower limit of the sufficiency range of the nutrient.

4. Coffee $\mathrm{Cu}$ nutrition has no effect neither on the concentrations of caffeine, trigonelline, proanthocyanidins, mannose, and galactose, nor on the leached potassium, color index, and electrical conductivity of raw coffee beans.

\section{References}

AMORIM, V.H. de; SILVA, D.M. Relationship between polyphenol oxidase activity of coffee beans and the quality of the beverage. Nature, v.219, p.381-382, 1968.

BROWN, J.C.; CLARK, R.B. Copper as essential to wheat reproduction. Plant and Soil, v.48, p.509-523, 1977. DOI: 10.1007/ BF02187257.

BUFFO, R.A.; REINECCIUS, G.A. Determination of linear response in the detection of mixtures of aroma compounds by atmospheric pressure ionization-mass spectrometry (API-MS). Flavour and Fragrance Journal, v.23, p.16-22, 2008. DOI: 10.1002/ffj.1849.

CAMPA, C.; BALLESTER, J.F.; DOULBEAU, S.; DUSSERT, S.; HAMON, S.; NOIROT, M. Trigonelline and sucrose diversity in wild Coffea species. Food Chemistry, v.88, p.39-43, 2004. DOI: 10.1016/j.foodchem.2004.01.020.

CARVALHO, V.D. de; CHAGAS, S.J. de R.; CHALFOUN, S.M.; BOTREL, N.; JUSTE JÚNIOR, E.S.G. Relação entre a composição físico-química e química do grão beneficiado e a qualidade de bebida do café. Pesquisa Agropecuária Brasileira, v.29, p.449-454, 1994.

CARVALHO, V.D.; CHAGAS, S.J.R.; CHALFOUN, S.M. Fatores que afetam a qualidade do café. Informe Agropecuário, v.18, p.5-20, 1997.

CLEMENTE, J.M.; MARTINEZ, H.E.P.; ALVES, L.C.; FINGER, F.L.; CECON, P.R. Effects of nitrogen and potassium on the chemical composition of coffee beans and on beverage quality. Acta Scientiarum. Agronomy, v.37, p.297-305, 2015. DOI: 10.4025/actasciagron.v37i3.19063.

DELL, B. Male sterility and anther wall structure in copperdeficient plants. Annals of Botany, v.48, p.599-608, 1981. DOI: 10.1093/oxfordjournals.aob.a086168.

FARAH, A.; MONTEIRO, M.C.; CALADO, V.; FRANCA, A.S.; TRUGO, L.C. Correlation between cup quality and chemical attributes of Brazilian coffee. Food Chemistry, v.98, p.373-380, 2006. DOI: 10.1016/j.foodchem.2005.07.032.

FARAH, A.; PAULIS, T. de; TRUGO, L.C.; MARTIN, P.R. Effect of roasting on the formation of chlorogenic acid lactones in coffee. Journal of Agricultural and Food Chemistry, v.53, p.1505-1513, 2005. DOI: 10.1021/jf048701t.

GONTIJO, R.A.N.; GUIMARÃES, R.J.; CARVALHO, J.G. Crescimento e teor foliar de nutrientes em cafeeiro decorrente da omissão isolada e simultânea de Ca, B, Cu e Zn. Coffee Science, v.3, p.124-132, 2008.

GOUlART, P. de F.P.; ALVES, J.D.; CASTRO, E.M. de; FRIES, D.D.; MAGALHÃES, M.M.; MELO, H.C. de. Aspectos histoquímicos e morfológicos de grãos de café de diferentes qualidades. Ciência Rural, v.37, p.662-666, 2007. DOI: 10.1590/ S0103-84782007000300010.

HAGERMAN, A.E. Tannin chemistry. 2002. Available at: $<$ http://www.users.muohio.edu/hagermae/>. Accessed on: Mar. 122013.

HÄNSCH, R.; MENDEL, R.R. Physiological functions of mineral micronutrients $(\mathrm{Cu}, \mathrm{Zn}, \mathrm{Mn}, \mathrm{Fe}, \mathrm{Ni}, \mathrm{Mo}, \mathrm{B}, \mathrm{Cl})$. Current Opinion in Plant Biology, v.12, p.259-266, 2009. DOI: 10.1016/j. pbi.2009.05.006.

HELRICH, K. (Ed.). Official methods of analysis of the Association of Official Analytical Chemists. $15^{\text {th }}$ ed. Arlington: Association of Official Analytical Chemists, 1990. v.1, p.685-1213.

KITZBERGER, C.S.G.; SCHOLZ, M.B. dos S.; PEREIRA, L.F.P.; BENASSI, M. de T. Composição química de cafés árabica de cultivares tradicionais e modernas. Pesquisa Agropecuária Brasileira, v.48, p.1498-1506, 2013. DOI: 10.1590/S0100204X2013001100011.

LOEFFLER, T.M.; TEKRONY, D.M.; EGLI, D.B. The bulk conductivity test as an indicator of soybean seed quality. Journal of Seed Technology, v.12, p.37-53, 1988. 
MALAVOLTA, E. Nutrição mineral e adubação do cafeeiro. São Paulo: Agronômica Ceres, 1993. 210p.

MARQUES, E.R.; BORÉM, F.M.; PEREIRA, R.G.F.A.; BIAGGIONI, M.A.M. Eficácia do teste de acidez graxa na avaliação da qualidade do café arábica (Coffea arabica L.) submetido a diferente períodos de temperaturas de secagem. Ciência e Agrotecnologia, v.32, p.1557-1562, 2008. DOI: 10.1590/ S1413-70542008000500030.

MARTINEZ, H.E.P.; CLEMENTE, J.M. O uso do cultivo hidropônico de plantas em pesquisa. Viçosa: Ed. da UFV, 2011. $76 \mathrm{p}$.

MARTINEZ, H.E.P.; MENEZES, J.F.S.; SOUZA, R.B. de; VENEGAS, V.H.A.; GUIMARÃES, P.T.G. Faixas críticas de concentrações de nutrientes e avaliação do estado nutricional de cafeeiros em quatro regiões de Minas Gerais. Pesquisa Agropecuária Brasileira, v.38, p.703-713, 2003. DOI: 10.1590/ S0100-204X2003000600006.

MARTINEZ, H.E.P.; POLTRONIERI, Y.N.; FARAH, A.; PERRONE, D. Zinc supplementation, production and quality of coffee beans. Revista Ceres, v.60, p.293-299, 2013. DOI: 10.1590/ S0034-737X2013000200020.

MAZZAFERA, P.; GONÇALVES, K.V.; SHIMIZU, M.M. Extração e dosagem da atividade da polifenoloxidase do café. Scientia Agrícola, v.59, p.695-700, 2002. DOI: 10.1590/S010390162002000400012.

MENDONÇA, L.M.V.L.; PEREIRA, R.G.F.A.; MENDES, A.N.G.; BORÉM, F.M.; MARQUES, E.R. Composição química de grãos crus de cultivares de Coffea arabica L. suscetíveis e resistentes à Hemileia vastatrix Berg et Br. Ciência e Agrotecnologia, v.31, p.413-419, 2007. DOI: 10.1590/S1413-70542007000200022.

MONTEIRO, M.C.; FARAH, A. Chlorogenic acids in Brazilian Coffea arabica cultivars from various consecutive crops. Food Chemistry, v.134, p.611-614, 2012. DOI: 10.1016/j. foodchem.2012.02.118.

MORAIS, S.A.L. de; AQUINO, F.J.T. de; NASCIMENTO, P.M. do; NASCIMENTO, E.A. do; CHANG, R. Compostos bioativos e atividade antioxidante do café conilon submetido a diferentes graus de torra. Química Nova, v.32, p.327-331, 2009. DOI: 10.1590/S0100-40422009000200011.

PILON, M.; ABDEL-GHANY, S.E.; COHU, C.M.; GOGOLIN, K.A.; YE, H. Copper cofactor delivery in plant cells. Current
Opinion in Plant Biology, v.9, p.256-263, 2006. DOI: 10.1016/j. pbi.2006.03.007.

RIBEIRO, D.E.; BOREM, F.M.; CIRILLO, M.A.; PRADO, M.V.B.; FERRAZ, V.P.; ALVES, H.M.R.; TAVEIRA, J.H. da $\mathrm{S}$. Interaction of genotype, environment and processing in the chemical composition expression and sensorial quality of Arabica coffee. African Journal of Agricultural Research, v.11, p.24122422, 2016. DOI: 10.5897/AJAR2016.10832.

SAGARDOY, R.; MORALES, F.; LÓPEZ-MILLÁN, A.-F.; ABADÍA, A.; ABADÍA, J. Effects of zinc toxicity on sugar beet (Beta vulgaris L.) plants grown in hydroponics. Plant Biology, v.11, p.339-350, 2009. DOI: 10.1111/j.1438-8677.2008.00153.x.

SALVA, T.J.G.; LIMA, V.B. de. A composição química do café e as características da bebida e do grão. O Agronômico, v.59, p.5759, 2007.

SCHERER, R.; RYBKA, A.C.P.; BALLUS, C.A.; MEINHART, A.D.; TEIXEIRA FILHO, J.; GODOY, H.T. Validation of a HPLC method for simultaneous determination of main organic acids in fruits and juices. Food Chemistry, v.135, p.150-154, 2012. DOI: 10.1016/j.foodchem.2012.03.111

SILVA, F.C. da (Ed). Manual de análises químicas de solos, plantas e fertilizantes. 2.ed. ver. e ampl. Brasília: Embrapa Informação Tecnológica, 2009. 627p.

SILVA, M.C. da; CASTRO, H.A.O.; FARNEZI, M.M. de M.; PINTO, N.A.V.D.; SILVA, E. de B. Caracterização química e sensorial de cafés da Chapada de Minas, visando determinar a qualidade final do café de alguns municípios produtores. Ciência e Agrotecnologia, v.33, p.1782-1787, 2009. Número especial. DOI: $10.1590 / \mathrm{S} 1413-70542009000700014$.

SINGLETON, V.L. The total phenolic content of grape berries during the maturation of several varieties. American Journal of Enology and Viticulture, v.17, p.126-134, 1966.

SLUITER, A.; HAMES, B.; RUIZ, R.; SCARLATA, C.; SLUITER, J.; TEMPLETON, D.; CROCKER, D. Determination of structural carbohydrates and lignin in biomass: Laboratory Analytical Procedure (LAP). [Colorado]: National Renewable Energy Laboratory, 2008. 16p. Technical Report NREL/TP-51042618 .

Received on January 6, 2017 and accepted on June 28, 2017 